\title{
Resistencia a la aspirina: llegó el momento de detectarla y de personalizar cada tratamiento
}

\author{
Aspirin resistance: It is time to detect it and to customize each treatment
}

\begin{abstract}
"Estudios recientes han encontrado que entre el $5 \%$ y más del $40 \%$ de las personas que toman aspirina son resistentes a la aspirina o no responden a ella. Esto significa que la aspirina no inhibe la coagulación de su sangre, como se supone que debería hacerlo." A. Pollack. New York Times. Nueva York, julio 20 de 2004.
\end{abstract}

Para la comunidad científica es una nueva noticia que las enfermedades cardiovasculares, incluidas las afecciones del corazón, del cerebro y de los vasos sanguíneos representan a nivel mundial la principal causa de muerte que, de acuerdo con la Organización Mundial de la Salud, son responsables de más de 17.500 .000 de muertes cada año: entre ellas, 7.400 .000 por ataques cardíacos y 6.700 .000 por ictus isquémico [1]. A nivel mundial se estima que el $1 \%$ de la población puede presentar un evento cardiovascular o cerebrovascular por año, de los que cerca del $50 \%$ se presentan en pacientes con enfermedad vascular preexistente [2, 3] y muchísimos de los cuales se pudieron haber prevenido con medidas tan simples como la antiagregación plaquetaria. Colombia no es ajena a esta problemática: la principal causa de morbimortalidad está relacionada con complicaciones cardiovasculares, con una tasa de mortalidad estimada para 2008 de 124,2 y 122,9 por 100.000 hombres y mujeres, respectivamente [4] y un aumento del 2,4\% por año, constituyéndose, por lo tanto, en un problema prioritario de salud pública [5]. Sumado a lo anterior y, lo más grave, es que en el país no existe la cultura de la antiagregación plaquetaria [6], como sí existe en países como Estados Unidos, en donde se consumen diariamente más de setenta millones de dosis de aspirina como prevención de eventos trombóticos [7].

Universalmente los enfoques para la reducción del riesgo cardiovascular, tanto en la prevención primaria como en la prevención secundaria, incluyen cambios del comportamiento, por ejemplo, la dieta [8], la actividad física [9] y dejar de fumar [10], y mejorar la gestión de los factores de riesgo, por ejemplo, el control de la diabetes [11], la hipertensión arterial [12] y los lípidos [13]. Además de estas medidas, los antiagregantes plaquetarios, en particular la aspirina, sola o asociada con otros antiagregantes, ha demostrado su eficacia en la disminución de recidivas en pacientes que han sufrido uno o varios accidentes trombóticos o con patología cardiovascular, incluyendo pacientes con angina de pecho, angina inestable, infarto agudo de miocardio, infarto cerebral y accidente isquémico transitorio [14-17], con una disminución del riesgo en torno de un $20 \%$ y un $25 \%$ [18]. El uso de la aspirina, tanto en la prevención primaria en pacientes de alto riesgo, sola [19] o en la prevención secundaria, usualmente asociada con otros antiagregantes, está universalmente incorporada en las guías de manejo [20-25].

Como se había sospechado desde 1985 [26], la resistencia, con desenlaces fatales, es un problema latente de la antiagregación plaquetaria, tanto con la aspirina como con los demás antiagregantes, siendo su prevalencia muy variable: tan baja como 
el 0,4\% [27] y tan alta como el 56,8\% [28]. Esta resistentes es explicable, en gran parte, en función de la definición de la misma, los métodos utilizados, la población estudiada y las comorbilidades de los pacientes incluidos, entre otras circunstancias, y presenta, de acuerdo con una revisión sistemática, una prevalencia media del 24\% (intervalo de confianza del 95\%: $20 \%$ al 28\%) [29], que indica que uno de cada cuatro pacientes que toman aspirina regularmente es susceptible de ser resistente al tratamiento y presentar una manifestación tromboembólica.

Con el desarrollo tecnológico de las dos últimas décadas es posible seguir a través de pruebas de laboratorio la antiagregación plaquetaria con aspirina y otros antiagregantes. Desde el punto de vista del laboratorio clínico, las pruebas disponibles en el medio y que mejor desempeño han mostrado para este fin son la agregometría óptica con ácido araquidónico [30] y el PFA (del inglés, Platelet Funtion Analizer)-100 (Siemens Healthcare Diagnostics, Inc., Deerfield, Illinois, Estados Unidos) $[31,32]$. Mediante el uso adecuado de estas pruebas de función plaquetaria es posible no solo ajustar la antiagregación a las condiciones personales de cada paciente, sino detectar oportunamente la resistencia a la aspirina cuando se presente y antes de que se manifieste como una complicación tromboembólica. Muy similar a lo que rutinariamente se hace con los pacientes que reciben cumarínicos como la warfarina, que deben ser monitoreados con un tiempo de protrombina periódicamente [33], todos los pacientes que reciben aspirina como antiagregante plaquetario, independiente de la causa por la cual se está indicando el fármaco, deberían ser monitoreados periódicamente, máxime cuando se dispone de la tecnología en el medio para hacerlo, como ya se mencionó, la prueba de agregación plaquetaria con ácido araquidónico y el PFA-100, y, sobre todo, si se tiene en cuenta la prevalencia tan alta de la resistencia a la aspirina [29] y las nefastas consecuencias que tiene en la clínica $[34,35]$ y que se pueden evitar con la detección oportuna de la resistencia, cuando se presenta.

La resistencia a los antiagregantes plaquetarios, en particular a la aspirina, crean una nueva realidad clínica que los médicos deberán agendar en su diaria actividad y los laboratorios clínicos habrán de incorporar en sus respectivos portafolios de servicios las pruebas relacionadas necesarias para su diagnóstico y seguimiento, acorde con la medicina centrada en el paciente, como claramente lo recomienda la Organización Mundial de la Salud (OMS) [36], en donde es inminente la optimización y la racionalización [37] en un mundo de inequidad y recursos limitados [38].

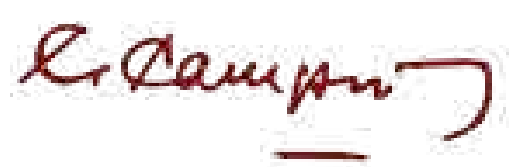

\section{Germán Campuzano Maya, MD}

Médico, especialista en Hematología y Patología Clínica, Director Laboratorio Clínico Hematológico

Editor, Medicina \& Laboratorio

Medellín, Colombia, febrero 2016 
1. World Health Organization. Global status report on noncommunicable diseases. Disponible en http://apps.who.int/iris/bitstre am/10665/148114/1/9789241564854_eng. pdf?ua=1. Consultado febrero 20162014 .

2. Yusuf S, Reddy $S$, Ounpuu $S$, Anand $S$. Global burden of cardiovascular diseases: part I: general considerations, the epidemiologic transition, risk factors, and impact of urbanization. Circulation 2001;104:2746-2753.

3. Yusuf S, Reddy S, Ounpuu S, Anand S. Global burden of cardiovascular diseases: Part II: variations in cardiovascular disease by specific ethnic groups and geographic regions and prevention strategies. Circulation 2001;104:28552864.

4. World Health Organization. Disease and injury country estimates, Burden of Disease 2008. Geneva: WHO; 2004 [consultado en ene 2016]. Disponible en: http://www.who. int/healthinfo/global burden disease/estimates country/en/.

5. López-Jaramillo P, Casas JP, Bautista L, Serrano NC, Morillo CA. An integrated proposal to explain the epidemic of cardiovascular disease in a developing country. From socioeconomic factors to free radicals. Cardiology 2001; $96: 1-6$.

6. Machado-Alba JE, García S, Calvo-Torres LF, Bañol-Giraldo AM. Patrones de prescripción del ácido salićlico. Rev Colomb Cardiol 2015;22:127-135.

7. Weisman SM, Graham DY. Evaluation of the benefits and risks of low-dose aspirin in the secondary prevention of cardiovascular and cerebrovascular events. Arch Intern Med 2002; 162:2197-2202.

8. Srinath Reddy K, Katan MB. Diet, nutrition and the prevention of hypertension and cardiovascular diseases. Public Health Nutr 2004;7:167-186.

9. Thompson PD, Buchner D, Pina IL, Balady GJ, Williams MA, Marcus BH, et al. Exercise and physical activity in the prevention and treatment of atherosclerotic cardiovascular disease: a statement from the Council on Clinical Cardiology (Subcommittee on Exercise, Rehabilitation, and Prevention) and the Council on Nutrition, Physical Activity, and Metabolism (Subcommittee on Physical Activity). Circulation 2003;107:3109-3116.

10. Rigotti NA, Pasternak RC. Cigarette smoking and coronary heart disease: risks and management. Cardiol Clin 1996;14:51-68.

11. Stratton IM, Adler AI, Neil HA, Matthews DR, Manley SE, Cull CA, et al. Association of glycaemia with macrovascular and microvascular complications of type 2 diabetes (UKPDS 35): prospective observational study. BMJ 2000;321:405-412.

12. Chobanian AV, Bakris GL, Black HR, Cushman WC, Green LA, Izzo JL, Jr., et al. Seventh report of the Joint National Committee on Prevention, Detection, Evaluation, and Treatment of High Blood Pressure. Hypertension 2003;42:1206-1252.

13. National Cholesterol Education Program Expert Panel on Detection E, Treatment of High Blood Cholesterol in A. Third Report of the National Cholesterol Education Program (NCEP) Expert Panel on Detection, Evaluation, and Treatment of High Blood Cholesterol in Adults (Adult Treatment Panel III) final report. Circulation 2002;106:3143-3421.

14. Lewis HD, Jr., Davis JW, Archibald DG, Steinke WE, Smitherman TC, Doherty JE, 3rd, et al. Protective effects of aspirin against acute myocardial infarction and death in men with unstable angina. Results of a Veterans Administration Cooperative Study. N Engl J Med 1983;309:396-403.

15. Farrell B, Godwin J, Richards S, Warlow C. The United Kingdom transient ischaemic attack (UK-TIA) aspirin trial: final results. J Neurol Neurosurg Psychiatry 1991;54:1044-1054.

16. Juul-Moller $S$, Edvardsson $N$, Jahnmatz B, Rosen A, Sorensen S, Omblus R. Double-blind trial of aspirin in primary prevention of myocardial infarction in patients with stable chronic angina pectoris. The Swedish Angina Pectoris Aspirin Trial (SAPAT) Group. Lancet 1992;340:1421-1425.

17. Patrono C, Coller B, FitzGerald GA, Hirsh J, Roth G. Platelet-active drugs: the relationships among dose, effectiveness, and side effects: the Seventh ACCP Conference on Antithrombotic and Thrombolytic Therapy. Chest 2004;126:234S-264S.

18. Antithrombotic Trialists Collaboration. Collaborative meta-analysis of randomised trials of antiplatelet therapy for prevention of death, myocardial infarction, and stroke in high risk patients. BMJ 2002;324:71-86.

19. Hayden M, Pignone M, Phillips $C$, Mulrow C. Aspirin for the primary prevention of cardiovascular events: a summary of the evidence for the U.S. Preventive Services Task Force. Ann Intern Med 2002;136:161-172.

20. Smith SC, Jr., Blair SN, Bonow RO, Brass LM, Cerqueira MD, Dracup K, et al. AHA/ ACC Guidelines for Preventing Heart Attack and Death in Patients With Atherosclerotic Cardiovascular Disease: 2001 update. A statement 
for healthcare professionals from the American Heart Association and the American College of Cardiology. J Am Coll Cardiol 2001;38:15811583.

21. AHA/ACC, National Heart $L$, Blood $I$, Smith SC, Jr., Allen J, Blair SN, et al. AHA/ACC guidelines for secondary prevention for patients with coronary and other atherosclerotic vascular disease: 2006 update endorsed by the National Heart, Lung, and Blood Institute. J Am Coll Cardiol 2006;47:2130-2139.

22. Sacco RL, Adams R, Albers G, Alberts MJ, Benavente $\mathbf{O}$, Furie $\mathbf{K}$, et al. Guidelines for prevention of stroke in patients with ischemic stroke or transient ischemic attack: a statement for healthcare professionals from the American Heart Association/American Stroke Association Council on Stroke: co-sponsored by the Council on Cardiovascular Radiology and Intervention: the American Academy of Neurology affirms the value of this guideline. Circulation 2006;113:e409-449.

23. King SB, 3rd, Smith SC, Jr., Hirshfeld JW, Jr., Jacobs AK, Morrison DA, Williams DO, et al. 2007 Focused Update of the ACC/AHA/SCAI 2005 guideline update for percutaneous coronary intervention: a report of the American College of Cardiology/American Heart Association Task Force on Practice Guidelines: 2007 Writing Group to Review New Evidence and Update the ACC/ AHA/SCAI 2005 Guideline Update for Percutaneous Coronary Intervention, Writing on Behalf of the 2005 Writing Committee. Circulation 2008;117:261-295.

24. Patrono C, Baigent C, Hirsh J, Roth G, American College of Chest P. Antiplatelet drugs: American College of Chest Physicians Evidence-Based Clinical Practice Guidelines (8th Edition). Chest 2008;133:199S-233S.

25. Harrington RA, Becker RC, Cannon CP, Gutterman D, Lincoff AM, Popma JJ, et al. Antithrombotic therapy for non-ST-segment elevation acute coronary syndromes: American College of Chest Physicians Evidence-Based Clinical Practice Guidelines (8th Edition). Chest 2008;133:670S-707S.

26. Mueller HS, Rao PS, Greenberg MA, Buttrick PM, Sussman, II, Levite HA, et al. Systemic and transcardiac platelet activity in acute myocardial infarction in man: resistance to prostacyclin. Circulation 1985;72:13361345.
27. Tantry US, Bliden KP, Gurbel PA. Overestimation of platelet aspirin resistance detection by thrombelastograph platelet mapping and validation by conventional aggregometry using arachidonic acid stimulation. J Am Coll Cardiol 2005;46:1705-1709.

28. Sane DC, McKee SA, Malinin AI, Serebruany VL. Frequency of aspirin resistance in patients with congestive heart failure treated with antecedent aspirin. Am J Cardiol 2002;90:893-895.

29. Hovens MM, Snoep JD, Eikenboom JC, van der Bom JG, Mertens BJ, Huisman MV. Prevalence of persistent platelet reactivity despite use of aspirin: a systematic review. Am Heart J 2007;153:175-181.

30. Born GV, Cross MJ. The aggregation of blood platelets. J Physiol 1963;168:178-195.

31. Favaloro EJ. Clinical utility of the PFA-100. Semin Thromb Hemost 2008;34:709-733.

32. Campuzano-Maya G. PFA-100: una nueva prueba de función plaquetaria sustituta del tiempo de sangría. Medicina \& Laboratorio 2013;19:411-448.

33. Hirsh J, Fuster V, Ansell J, Halperin JL, American Heart A, American College of Cardiology F. American Heart Association/ American College of Cardiology Foundation guide to warfarin therapy. Circulation 2003; 107:1692-1711.

34. Snoep JD, Hovens MM, Eikenboom JC, van der Bom JG, Huisman MV. Association of laboratory-defined aspirin resistance with a higher risk of recurrent cardiovascular events: a systematic review and meta-analysis. Arch Intern Med 2007;167:1593-1599.

35. Krasopoulos G, Brister SJ, Beattie WS, Buchanan MR. Aspirin "resistance" and risk of cardiovascular morbidity: systematic review and meta-analysis. BMJ 2008;336:195-198.

36. Eisenberg JM. The Agency for Healthcare Research and Quality: new challenges, new opportunities. Health services research 2000;35:xi-xvi.

37. Plebani M, Lippi G. Improving diagnosis and reducing diagnostic errors: the next frontier of laboratory medicine. Clin Chem Lab Med 2016;54:1117-1118.

38. Lippi G, Plebani M. Improving accuracy of diagnostic studies in a world with limited resources: a road ahead. Ann Transl Med 2016;4:43. 